\title{
Smart Halal Destination Ecosystem: The Exploration of Halal Tourism Ecosystem Model
}

\section{Sumaryadi1, Anang Sutono2*, Wisnu Rahtomo3, Christian Helmy Rumayar", Faisal Fahdian Puksi ${ }^{5}$}

Department of Tourism Business Management, NHI Bandung School of Tourism Bandung, Indonesia ${ }^{1,2}$ Department of Tourism Destination Management, NHI Bandung Tourism Bandung, Indonesia ${ }^{3}$ Department of Culinary Arts, NHI Bandung Tourism College Bandung, Indonesia ${ }^{4}$ Department of Tour Management, NHI Bandung Tourism College Bandung, Indonesia ${ }^{5}$ Email: sumaryadi@stp-bandung.ac.id

\begin{abstract}
One of Indonesia's strategic steps in encouraging the development of halal tourism is by conducting an assessment and ranking of the IMTI (Indonesia Muslim Travel Index). IMTI has been carried out in 2018 and 2019. The challenge faced in implementing a smart halal destination is how to integrate innovative and smart solutions that maximize the travel experience, and in accordance with local realities. Coordination and sharing and systematic and widespread utilization of halal tourism data for value creation, efficient integrated systems and services is still a big challenge.

SMART Halal Destination is an "ecosystem that is effective, efficient, and integrated through a technology system, to build competitive Muslim-friendly destinations".
\end{abstract}

Keywords: Halal Tourism; Halal Destination; Destination.

\section{A. INTRODUCTION}

Halal tourism has been recorded steadily growing since 2000.growth Globalof Muslim travelers has grown rapidly from 25 million in 2000 to 140 million in 2018, or growing $25 \%$ / year. This growth is predicted to continue to increase to 230 million with a turnover of USD 300 billion (4,200 trillion) in 2026. (Mastercard - Crescent Rating, 2019).

Currently, halal tourism has become a global mainstream market, not just a niche market. Halal tourism is a current and promising future tourism trend. Efforts to meet the need for Muslim-friendly tourist destinations are a very rational and profitable choice.

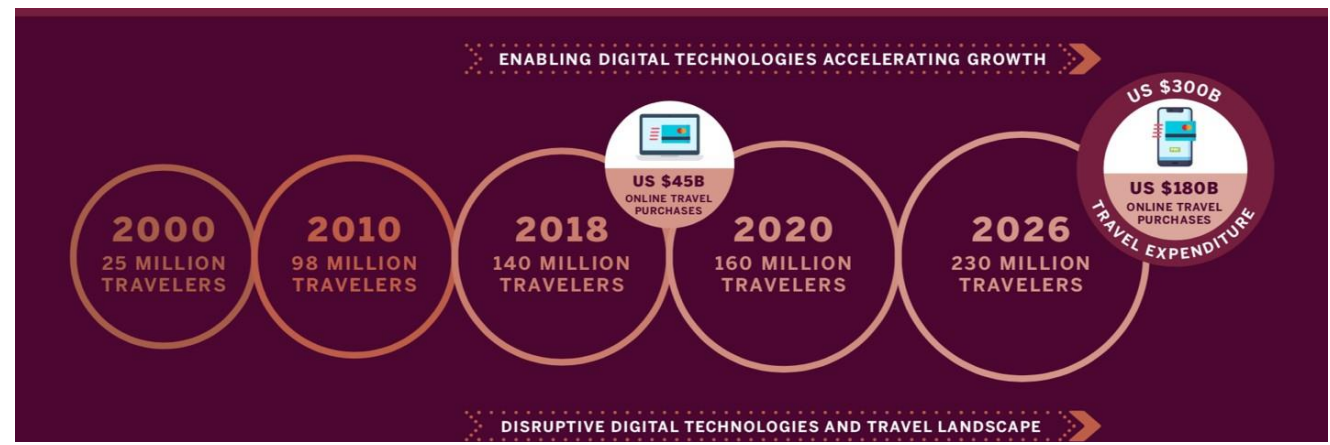

Figure 1 Muslim Travelers Global Growth Prediction

Source: MasterCard - Crescent Rating, 2019

* Corresponding author

Received: August 03, 2020; Revised: November 09, 2020; Accepted: December 21, 2020 
Many countries, both Islamic and non-Islamic countries, believe in this and seek to make halal tourism one of the focuses of tourism development (Duman, 2011; Shakona et al., 2015), including Indonesia. Until 2018, the Indonesian halal tourism market grew by 15\% and received visits of 2.6 million Muslim foreign tourists (Ministry of Tourism's Halal Tourism Development Acceleration Team, 2019).

Indonesia, as the largest Muslim country in the world, has enormous potential to become the world's halal tourism destination. The strength of halal tourism lies in the readiness of the destination to receive Muslim tourist visits. (Battour \& Ismail, 2016; Wall \& Mathieson, 2006; Weidenfeld \& Ron, 2008). Tourism destinations must be able to meet the specific needs of Muslim tourists during a tour. The development of components of tourism products, which include amenities, attractions and accessibility, need to be aligned with the profiles, needs, expectations and preferences of Muslim tourists. (M. Battour et al., 2011; Morrison, 2013). This is very important to create quality products for halal tourism destinations. (Eid \& Hatem El-Gohary, 2014; Shakona et al., 2015)

Fulfilling the needs, expectations and preferences of Muslim tourists will make tourists feel satisfied (Tribe \& Snaith, 1998; Truong \& Foster, 2006) and increase the potential for repeat tourist visits. (Chang, Backman, \& Huang, 2014). The existence of additional 'requirements' that are specific to fulfilling the needs of being a Muslim when traveling, demands that destinations understand the profile of Muslim tourists visiting, and make this information one of the main considerations in its development. (Pizam, Neumann, \& Reichel, 1978; Eid \& El-Gohary, 2014; Shakona et al., 2015).

The Ministry of Tourism (2017) has designated halal tourism as one of the leading themes for national tourism development. 10 leading halal tourism destinations have been determined, namely: Aceh, West Sumatra, Riau and Riau Islands, DKI Jakarta, West Java, Central Java, Yogyakarta, Malang Raya, Lombok, and Makassar and its surroundings.

The development of Indonesian halal tourism is gaining momentum in 2019. Indonesian halal tourism has won 1st place as the world's best halal tourism destination with Malaysia (Mastercard Crescent Rating, 2019). However, this achievement has not been accompanied by the ability to reach Muslim foreign tourists. Indonesia is still far behind Malaysia. Malaysia managed to reach 5.38 million Muslim foreign tourists in 2017 (Statista, 2020), compared to Indonesia which was only 2.6 million in 2018.

One of Indonesia's strategic steps in encouraging the development of halal tourism is by conducting an assessment and ranking of the IMTI (Indonesia Muslim Travel Index). IMTI has been carried out in 2018 and 2019. The results of the IMTI are as follows:

\section{Table 1 Ranking of Indonesia's Leading Halal Tourism Destinations - IMTI}

\begin{tabular}{|c|c|c|c|c|c|}
\hline DESTINATION & $\begin{array}{c}\text { IMTI 2018 } \\
\text { SCORE }\end{array}$ & $\begin{array}{c}\text { IMTI 2018 } \\
\text { RANK }\end{array}$ & $\begin{array}{c}\text { IMTI 2019 } \\
\text { SCORE }\end{array}$ & $\begin{array}{c}\text { IMTI 2019 } \\
\text { RANK }\end{array}$ & CHANGE \\
\hline $\begin{array}{c}\text { Lombok (West Nusa } \\
\text { Tenggara) }\end{array}$ & 58 & 1 & 70 & 1 & +12 \\
\hline Aceh & 57 & 2 & 66 & 2 & +9 \\
\hline Riau \& Riau Islands & 50 & 7 & 63 & 3 & +13 \\
\hline Jakarta & 56 & 3 & 59 & 4 & +3 \\
\hline West Sumatera & 55 & 4 & 59 & 5 & +4 \\
\hline West Java & 51 & 6 & 52 & 6 & +1 \\
\hline Yogyakarta & 51 & 5 & 52 & 7 & +1 \\
\hline Central Java & 47 & 9 & 49 & 8 & +2 \\
\hline East Java (Malang Area) & 48 & 8 & 49 & 9 & +1 \\
\hline South Sulawesi (Makassar & 30 & 10 & 33 & 10 & +3 \\
\hline \& Surroundings) & & & & +3 & +3 \\
\hline
\end{tabular}

Source: MasterCard - Crescent Rating, 2019 
The existence of IMTI is considered capable of capturing positive growth in 10 of Indonesia's leading tourism destinations. This can be seen from the positive growth of all leading halal tourism destinations from 2018 to 2019.

IMTI in 2018 and 2019 was carried out using the same criteria as GMTI (Global Muslim Travel Index). The IMTI assessment is also carried out directly by MasterCard - Crescent Rating, the organizer of the GMTI. The use of the GMTI criteria, which are actually designed to assess a country globally, is considered necessary to adjust the indicators used to be more relevant to the characteristics of tourism destinations in Indonesia.

Thus, the availability of an assessment model for Indonesian halal tourism destinations becomes is indispensable. Halal tourism destinations require assessment information, what are the current conditions, whether the development that has been carried out has been successful or not, to how it compares with other destinations. These questions must be answered in a measured and accurate manner.

In general, the answer that is often used to this question is that a successful destination is the one most visited by Muslim tourists. However, the answer is only able to describe the general condition. How the condition of the ecosystem that supports the development of halal tourism destinations has not been revealed. In addition to being used to assess and rank halal tourism destinations, this assessment model is also used to identify the condition of the Indonesian halal tourism development ecosystem. Thus, the results of the assessment carried out will be able to provide a guide for preparing the steps for the development undertaken (roadmap development). With the assessment and ranking activities of Indonesian halal tourism destinations, it is believed that the comparative and competitive advantages of Indonesian halal tourism will increase (Ritchie \& Crouch, 1999, 2010).

Based on the explanation above, it is very necessary to have a model of halal tourism destinations as a concept that is oriented towards ecosystem development, and in accordance with the characteristics of Indonesian halal tourism. Therefore, it is important to conduct research on "Smart Halal Destination Model Development".

\section{B. Literature Review}

\section{Halal Tourism Today's tourism}

Activities produce many new concepts so that the essence of people to travel is not just for fun but also to add new knowledge and experiences without having to abandon the principles of values they hold. From there, a tourism concept emerged based on the needs of tourists related to fulfilling religious values without having to reduce the core concept of traveling.

According to the International Muslim Ulama Association, the term halal is defined as "something that is permissible, with respect to which there are no restrictions, and to do it in accordance with the law of Allah," (Al-Qaradawi, 2013). Therefore, the term Halal means something that is allowed based on Islam or known as Sharia law. Halal refers to the five acts that classify the morality of human actions in Islam, namely into Fard (obligatory), mustahabb (recommended), Makruh (disliking), and Haram (prohibited).

From an Islamic perspective, Halal tourism can be defined as a tourist activity that is allowed because it follows Islamic teachings. Halal tourism is a tourism activity that adheres to Islamic philosophical values that adjust to the needs of tourists for their needs in accordance with Islamic principles, such as the availability of halal products, the availability of clean and comfortable places of worship, accommodation that meets the needs of the Muslim community. In other words, Muslim tourists want to do tourism activities but religious principles can still be applied in every life and tour. 
Islamic tourism can be simply defined as tourism by Muslims (Zamani-farahani \& Henderson, 2010). The terminology of sharia tourism, halal tourism, Muslim friendly tourism is a term that is often used interchangeably even though these terms have a slight difference. (Razzaq, Hall, \& Prayag, 2016) Halal tourism or Islamic tourism is tourism and hospitality created by consumers and producers in accordance with Islamic teachings.

The concept of halal tourism was born from an effort to meet the needs of tourists to be able to carry out their religious principles while traveling. Tourism destinations must be able to meet the specific needs of Muslim tourists during a tour. The development of components of tourism products, which include amenities, attractions and accessibility, need to be aligned with the profiles, needs, expectations and preferences of Muslim tourists. (M. Battour et al., 2011; Morrison, 2013). The existence of additional 'requirements' that are specific to fulfilling the needs of being a Muslim when traveling, demands that destinations understand the profile of Muslim tourists visiting, and make this information one of the main considerations in its development. (Pizam, Neumann,\& Reichel, 1978; Eid \& El-Gohary, 2014; Shakona et al., 2015)

Halal tourism also starts from the marketing strategy section by looking at the potential aspects of a specific or specific(marketniche market). The Muslim tourist market has a special character related to Islamic values that must be fulfilled, including in influencing the decision to visit a destination and can also determine the level of satisfaction in doing tourism in a destination (Tribe \& Snaith, 1998; Truong \& Foster, 2006) and increase the potential for repeat tourist visits (Chang et al., 2014). The strength of halal tourism lies in the readiness of the destination to receive Muslim tourist visits. (Battour \& Ismail, 2016; Wall \& Mathieson, 2006; Weidenfeld \& Ron, 2008). This is very important to create quality products for halal tourism destinations (Eid \& Hatem El- Gohary, 2014; Shakona et al., 2015).

In its development, the perspective on halal tourism must be interpreted appropriately so that it does not cause confusion and misunderstanding from various parties. Therefore, an understanding of the concept of halal tourism is needed. Departing from a unique character related to the Muslim tourist market, the approach to the concept of halal tourism that can be used comes from Sutono (2019) in the Indonesian Halal Tourism Strategic Plan (Ministry of Tourism, 2019b), namely:

"Halal Tourism is a set of an extended Services of Amenities , Attractions, and Accessibilities intended to deliver and fulfill Muslim Travelers' Experiences, Needs and Wants."

"Halal Tourism is a set of additional services for Amenities, Tourist Attractions, and Accessibility which are aimed and provided to meet the experiences, needs and desires of Muslim tourists."

Halal tourism destinations are developed using principles based on the Tourism Development Policy in Indonesia, namely Law No. 10 of 2009 concerning Tourism, which states that tourism is carried out with the principle:

a) upholding religious norms and cultural values as the embodiment of the concept of life in the balance of the relationship between humans and God Almighty, the relationship between humans and fellow humans, and the relationship between humans and the environment;

b) uphold human rights, cultural diversity and local wisdom;

c) provide benefits for the people's welfare, justice, equality and proportionality;

d) preserving nature and the environment;

e) empowering local communities;

f) guaranteeing inter-sectoral, inter-regional, central and regional integration which constitutes one systemic unit within the framework of regional autonomy, as well as integration between stakeholders;

g) comply with the world tourism code of ethics and international agreements in the tourism sector; and 
h) strengthen the integrity of the Unitary State of the Republic of Indonesia.

Specifically, as stated in the Halal Tourism Development Guide (Ministry of Tourism, 2019a), the implementation of halal tourism destination development is guided by the following principles:

a) Regulate what is necessary, namely in Islam there are obligations that Muslims must do. In carrying out these obligations, it requires the availability of facilities and infrastructure. Regulating the provision of facilities and infrastructure as well as the ease of carrying out other obligations is what is meant by regulating what is needed;

b) Facilitating, means that things that are arranged or requested to be provided are those that do not require a large investment and are easy to implement;

c) In accordance with the ability, namely specifically for the Industry, it canchoose to provide basic needs or needs that are more complete (moderate);

d) Gradually, that is, industries or destinations can start by providing or preparing basic needs and can increase by providing more complete needs that will make Muslim tourists more comfortable;

e) Priority scale, namely what is provided first are basic needs and in this case are needs that are not possible for Muslim tourists to prepare themselves, such as advice and infrastructure for worship, the availability of food and drinks that are guaranteed halalness;

f) Inclusive, that is, this provision of services can be carried out and prepared by Muslims and nonMuslims and can be enjoyed by Muslim tourists as well as non- Muslim tourists, because in preparing the needs of Muslim tourists it will not interfere with the convenience of non-Muslim tourists, including the provision of halal food which can still be consumed. by non-Muslim tourists.

\section{Smart City}

Smart City is a city that uses information and communication technology (ICT) to increase operational efficiency, share information with the public, and improve the quality of government services and the welfare of citizens.

Although the exact definition varies, the overarching mission of a Smart City is to optimize the functioning of the city and promote economic growth while improving the quality of life for its citizens using smart technology and data analysis. Value is given to Smart Cities based on what they choose to do with their technology, not just how much technology they have.

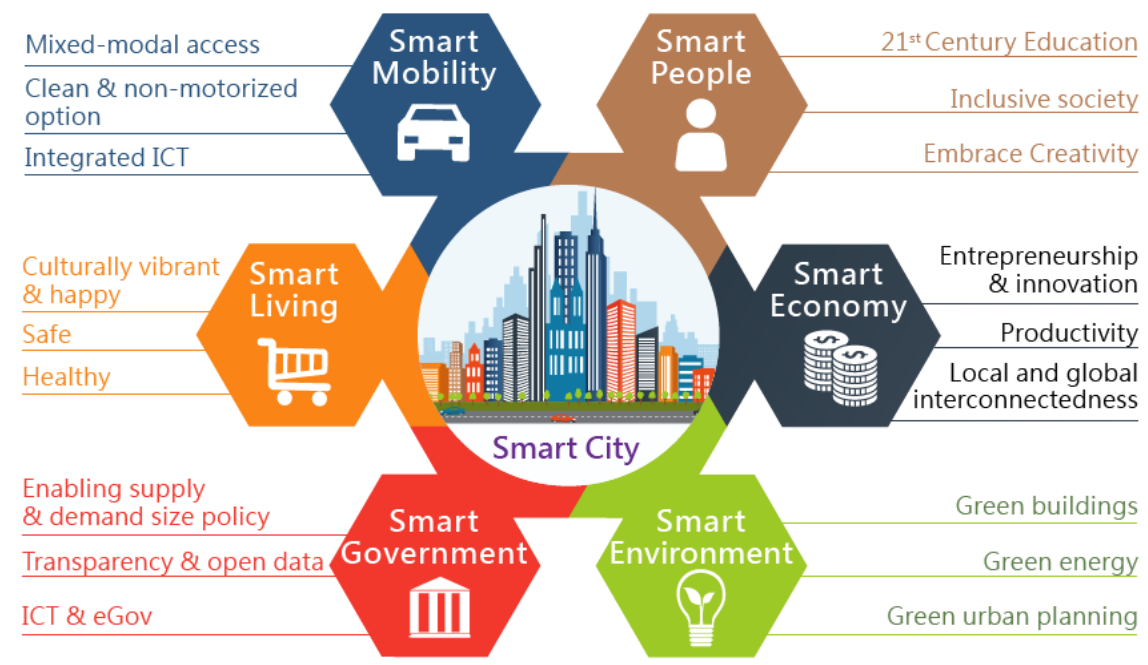

Figure 2 Smart City Model

\section{Source: www.thesmartcityjournal.com}




\section{Smart Tourism}

Smart tourism is defined as the latest stage of tourism development influencedby the evolution of technology and information developments (Gajdosik, 2018). Smart tourism is all the use of ICT to obtain information related to tourism activities (Okty, 2017). Smart tourism regulates and delivers experiences and services in tourism by utilizing technology produced by stakeholders who are members of theecosystem Smart Tourism such as producers, distributors, tourists themselves, government agents, travel agents and actors using ICT. (Su et al, 2011) Smart Tourism is the use of hardwareplatforms and software forinformation and services Smart City that are well utilized to lead to an integrated tourism market.

The main thing that attracts and influences the behavior and interests of tourists so that they become interested in switching to try Smart Tourism is experience. The main components in Smart Tourism are as follows: IoT (Internet of things), Mobile communication, Cloud computing, Artificial Intelligence (Guo et al, 2014).

\section{Smart Destination}

Smart Destination is an innovative tourist destination, built on a cutting-edge technology infrastructure that ensures the development of a sustainable tourist area, accessible to everyone, which facilitates interaction and integration of visitors with their environment, improves the quality of experience at the destination, and improves the quality of life of residents. (UNWTO, Lopez de Avila, 2015).

Smart Destination is an ecosystem that is mostly developed through the use of effective technology with the aim of improving the quality of life for citizens, which is achieved through efficient integrated systems and services.

\begin{tabular}{|c|c|}
\hline $\begin{array}{l}\text { SMART ECONOMY } \\
\text { (Competitiveness) }\end{array}$ & $\begin{array}{c}\text { SMART PEOPLE } \\
\text { (Social and Human Capital) }\end{array}$ \\
\hline $\begin{array}{l}\text { - Innovative spirit } \\
\text { - Entrepreneurship } \\
\text { - Economic image \& trademarks } \\
\text { - Productivity } \\
\text { - Flexibility of labour market } \\
\text { - International embeddedness } \\
\text { - Ability to transform }\end{array}$ & $\begin{array}{l}\text { - Level of qualification } \\
\text { - Affinity to lifelong learning } \\
\text { - Social and ethnic plurality } \\
\text { - Flexibility } \\
\text { - Creativity } \\
\text { - Cosmopolitanism/Open-mindedness } \\
\text { - Participation in public life }\end{array}$ \\
\hline $\begin{array}{l}\text { SMART GOVERNANCE } \\
\text { (Participation) }\end{array}$ & $\begin{array}{l}\text { SMART MOBILITY } \\
\text { (Transport and ICT) }\end{array}$ \\
\hline $\begin{array}{l}\text { - Participation in decision-making } \\
\text { - Public and social services } \\
\text { - Transparent governance } \\
\text { - Political strategies \& perspectives }\end{array}$ & $\begin{array}{l}\text { - Local accessibility } \\
\text { - (Inter-)national accessibility } \\
\text { - Availability of ICT-infrastructure } \\
\text { - Sustainable, innovative and safe transport } \\
\text { systems }\end{array}$ \\
\hline $\begin{array}{l}\text { SMART ENVIRONMENT } \\
\text { (Natural resources) }\end{array}$ & $\begin{array}{l}\text { SMART LIVING } \\
\text { (Quality of life) }\end{array}$ \\
\hline $\begin{array}{l}\text { - Attractivity of natural conditions } \\
\text { - Pollution } \\
\text { - Environmental protection } \\
\text { - Sustainable resource management }\end{array}$ & $\begin{array}{l}\text { - Cultural facilities } \\
\text { - Health conditions } \\
\text { - Individual safety } \\
\text { - Housing quality } \\
\text { - Education facilities } \\
\text { - Touristic attractivity } \\
\text { - Social cohesion }\end{array}$ \\
\hline
\end{tabular}

Source: (Giffinger, Haindlmaier, \& Kramar, 2010:305).

Figure 3 Smart Destination Model 


\section{Smart Mobility (Transport \& ICT)}

Refers to the development of technology to increase urban mobility \& low environmental impact, consisting of: Local Accessibility, international accessibility, Availability of ICT-infrastructure, Sustainable, innovative andsafe transport systems.

\section{Smart Governance (Participation)}

Refers to political strategies and policies, including expanded urban planning that enables the coproduction of public services including; Participation in decision- making, Public and social service, Transparent governance, Political Strategies \& Perspectives.

\section{Smart Economy (Competitiveness)}

Smart Economy in the context of competitiveness is a perspective of a holistic, responsible and transformative economic transaction that leads to flexibility by prioritizing the innovation process by increasing connectivity through information technology. Smart Economy in general can help growth in terms of; Innovative spirit, Entrepreneurship, Economic image \& trademarks, Productivity, Flexibility of labor market, International embeddedness, Ability to transform.

\section{Smart People (Social and Human Capital)}

Refers to social life, with a level of qualification Level of qualification, Affinity to lifelong learning, Social and ethnic plurality, Flexibility, Creativity, Cosmopolitarism / Open-mindedness, Participation in public life.

\section{Smart Living (Quality of Life)}

Smart Living is important in building a Smart Destination. Smart Living always refers to the quality of life in a livable and safe environment. It consists of infrastructure that supports everyday life.

Smart Living has a very strong orientation towards; Cultural facilities, Health conditions, Housing quality, Education facilities, Touristic attractivity, Social cohesion.

\section{Smart Environment (Natural resources)}

Smart Environment is also a fundamental component in building a Smart Destination. This refers to concern for natural resources and planetary culture. The essential essence in a Smart Environment is focused on; Attractivity of natural conditions, Reduction of $\mathrm{CO} 2$ emissions Environment protection, Using renewable energy sources, Monitoring on energy consumptions, Sustainable resource management.

\section{Destination Product}

Understanding the management of tourism destinations (Destination Management), according to (Morrison, 2013) says that destination management is an effort to coordinate and integrate all elements in the destination mix (accommodation, transportation, attractions and others) in a geographic area based on regional planning strategies or the area according to its development planning portfolio.

The destination mix element consists of attractions and events, facilities (hotels, restaurants, etc.), transportation, infrastructure, and hospitality resources (Morrison, 2013). In relation, destination management includes building a destination image, branding, as well as marketing and communication of all the places that are offered to tourists. The destination management organization (DMO) has overall responsibility for the coordination and integration of elements of the destination mix, and for destination marketing. DMOs Spread across the globe and spanning many different sizes and types of organizations, DMOs have been around for at least 100 years. Many DMOs are held by government departments, while 
others resemble governments. The structure of the DMO varies according to local practices and the system of government in force.

The mix of destinations and destination products is a similar concept. Each destination has four components of destination products (Morrison, 2013):

Physical Products: This includes types of physical objects such as attractions, facilities, transportation, and infrastructure. Attractions play an important role in attracting tourists to destinations. There must be convenient transportation access to destinations and good infrastructure (eg, electric power, sewerage communications, telephones, etc.) to support a safe and enjoyable journey within the destination. There must be adequate hotels and restaurants to meet the needs of tourists.

Local HR: local people provide the hospitality resources to live together as hosts and provide personal service. Local culture and lifestyle are also often very attractive to tourists. citizens must be made aware of the benefits of tourism.

Packages: All destinations have a set of packages and programs that travelers can purchase and use. Packages are assembled by travel agents, tour operators and others, and incorporate many elements of the total travel experience. They are organized either by theme or route of travel, and are often based on industry partnerships. Packages can be purchased through traditional retail channels including at travel agencies, or purchased online.

Programs: Events, festivals and activities arranged or programmed for tourists. Welldesigned and promoted festivals and events can attract tourists to a destination, so they can share the role of attraction with attractions. A program of activities is also pre-arranged for tourists with special interests.

Based on CUC-UEM (Canadian universities consortium - urban environmental management project) The destination management process requires destinations to develop products, whether in the form of cultural, natural or intangible natural destinations, to meet market needs. The old assumption that "product will create its own demand" is no longer relevant today. On the contrary, there must be a clear relationship between the nature of the product and the market. This process is more complex than other forms of a product since very often tourism planners and managers deal with irreplaceable and fragile resources. The challenge is to achieve a match between the product and the market.

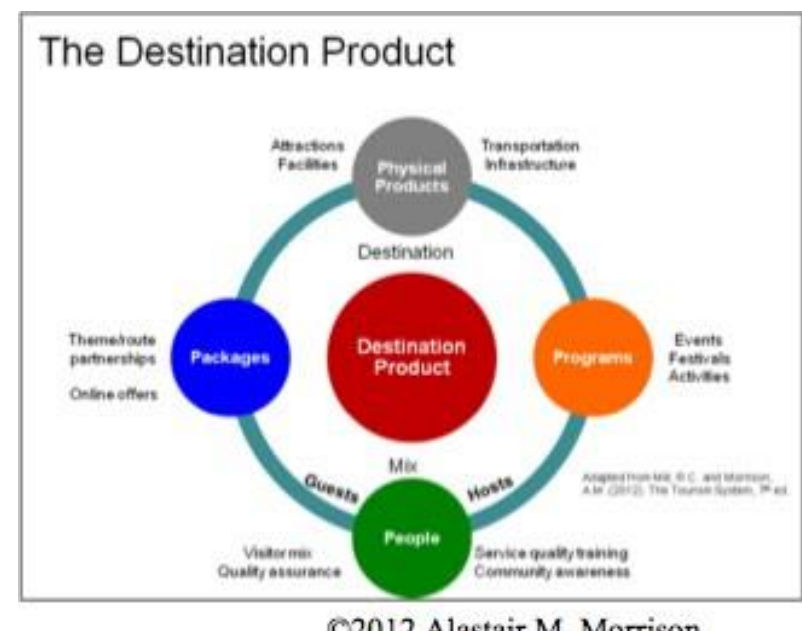

Figure 4 The Destination Product 


\section{Tourism Development Model and Halal Tourism}

\section{ACES Model, Global Muslim Travel Index (GMTI)}

Based on Mastercard Crescentrating, the agency has been evaluating halal tourist destinations since 2011, ranking them according to how well they serve Muslim travelers. The Mastercard-Crescentrating (GMTI) Global Muslim Travel Index was introduced in 2015 to create an Index to reference tourist destinations in the Muslim Travel Market. The index is an invaluable tool for stakeholders in the travel and hospitality sector to help understand how Muslim travel is affecting the travel market as a whole.

The indicators developed in the ranking of the GMTI model are ACES (Access, Communication, Environment, Service), as follows:

\begin{tabular}{|l|}
\hline \multicolumn{1}{|c|}{ Access } \\
\hline Air Access \\
Rail Access \\
Sea Access \\
Road Infrastructure \\
\\
\end{tabular}

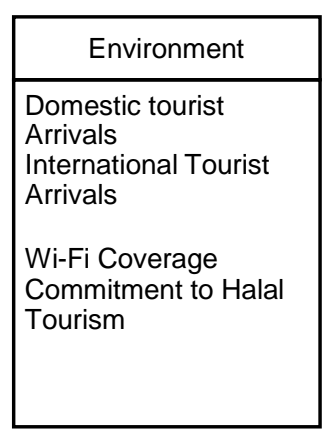

\begin{tabular}{|l|}
\hline \multicolumn{1}{|c|}{ Services } \\
\hline Halal Restaurants \\
Mosques \\
Airports \\
Hotels \\
Attractions \\
\\
\hline
\end{tabular}

Figure 5 ACES Indicators

\section{Access}

Access in this ACES Model includes easy air access which includes a choice of domestic and international flight routes as well as the choice of available airlines, the availability of train access as well as the types of train services offered and available routes both within cities and between cities / provinces, then the availability of sea or port / water access, then infrastructure or road quality in destinations such as road quality , the availability of street lighting, other supporting facilities such as CCTV, etc., these components are assessed as the ease of accessibility of the destination through a choice of several modes of transportation so that it can meet the needs of tourists to arrive at their destination.

\section{Communication}

This communication component considers several sub-criteria, including Muslim visitor guides through the completeness of existing information, the suitability of the choice of language used in the destination market, as well as the form of the Muslim visitor guide and the ease of obtaining it, education stakeholder through exposure, discussion and training, outreach methods. market through special events or expos, foreign language skills of tour guides in the language of the majority of destination tourists, as well as digital marketing, this aspect is intended so that information about halal tourism can be conveyed properly to tourists, while education stakeholder can be carried out through training, workshops, or discussion forums. for the development of halal tourism in these destinations. The use of international languages that are widely used by Muslim tourists, such as Arabic and English, also needs to be considered in conveying information about halal tourism. 


\section{Environment}

In the environmental aspect, the ACES model focuses more on the arrival of foreign and domestic Muslim tourists, if Muslim tourists tend to be many, then other Muslim tourists will tend to be more comfortable in their destination, the coverage of WiFi availability (number of WiFi points) is both accessible for free. as well as paid and fast internet connection, then the commitment of these destinations in the implementation of halal tourism through policies issued by the regions shows how important and how regional priorities are for the development of halal tourism, WiFi or internet access is important for the development of halal tourism, and tourism in general. This internet is needed by tourists, especially in public places to support tourist trips, especially in the process of searching for information and online reservations for both attractions and accommodation and transportation, even to the process of sharing traveling experiences through various platforms. both the application and the website.

\section{Services}

While the service component includes the availability of facilities in the form of halal restaurants, mosques, airports, hotels and attractions, this service is important for Muslim tourists to be able to travel freely and still be able to fulfill their religious needs while traveling, the certification aspect is also a global issue related to tourism. halal, this certification is a guarantee and a source of trust for Muslim tourists. The availability of prayer rooms in public facilities as well as water friendly facilities related to the need for ablution is also very important for Muslim tourists, and the existence of privacy for Muslim tourists, especially Muslim women, can add to the value of the Muslim tourist experience, in providing hotels, the availability of certified Sharia hotels is one of the components that become value added for destinations, because the number of hotels with Sharia certificates is still very minimal, besides that halal certification for restaurants, food and beverage outlets and hotel kitchens is also a guarantee for Muslim tourists to be able to enjoy a meal while traveling in a destination.

\section{Global Islamic Economy (GIE) Indicator}

Dinar Standard the State of the Global Islamic Economy Report 2019/2020 is the seventh annual edition produced by Dinar Standard in collaboration with the Dubai Islamic Economy Development Center and Salaam Gateway. The report focuses on 1.8 billion Muslim consumers worldwide. This year's report estimates that Muslims spent USD 2.2 trillion in 2018 across the food, pharmaceutical and lifestyle sectors influenced by ethics inspired by Islamic beliefs and consumer needs. This expenditure reflects a healthy $5.2 \%$ year-on-year growth and is now projected to reach USD 3.2 trillion by 2024. Cumulative Annual Growth Rate ("CAGR") of 6.2\%. In addition, Islamic financial assets were reported to have reached USD 2.5 trillion in 2018 (Dinar Standard, 2019). With important developments over the past year, the Islamic economy has built an increasingly important foothold in the global economy, driven by increasing Muslim consumers and the growing demand for specialty products and services under Islamic law such as the global sub-sector of halal (permitted) food, cosmetics and food. pharmacy, financial services, fashion / fashion, Muslim friendly travel, and Islamic media.

Global growth is supported by key drivers which include the growth and well- being of a high Muslim population, increasing compliance with ethical values, ongoing engagement by multinational companies and global investors, and the development of a number of national strategies dedicated to halal products and related opportunities. halal. The main drivers (key drivers) in the development of the halal industry are:
a) National strategy for
b) investment in 
c) halal food Islamic

d) finance

e) Muslim-friendly tourism

f) Fashion

g) Halal medicine Halal

h) cosmetics Halal

i) media and recreation

Muslim-friendly tourism, which meets the needs of religious-based Muslim tourists, is more widespread than ever, with offers ranging from beach resorts to family- oriented hotels, and from travel agents to apps that book and rate vacations. Over the past year, numerous online travel agencies have emerged with a new focus on Saudi Arabia's growing Umrah and wider tourism market, attracting the largest investment in the Muslim-friendly travel market.

In the State of the Global Islamic Economy Report 2018/2019 (Thomson Reuters, 2018) there is a Halal Travel Indicator to evaluate the country and the development of its Muslim travel market ecosystem. This indicator is part of the overall Global Islamic Economy (GIE) Indicator. The Halal Travel Indicator does not focus on the overall size and growth trajectory of a country; conversely, this indicator evaluates countries based on the relative strength of their ecosystems for developing a Muslim-friendly tourism sector. The indicator assigns equal weight to the four metric categories and has the following metrics for each of them:

a) The driver of supply is related to the size of the country (incoming inbound tourists / Muslim inbound travel)

b) Governance (halal friendly ecosystem)

c) Awareness (number of news articles and related events / awareness)

d) Social (contribution of the travel sector to employment / social)

\section{Travel and Tourism Competitiveness (TTCI) Framework, WEF}

The Travel and Tourism Competitiveness Index / TTCI (World Economic Forum, 2019) is a report on the results of the assessment and ranking of world tourism competitiveness conducted by the World Economic Forum, located in Geneva - Switzerland. This report presents information compiled with methodologies in a systematic, measurable, accurate manner, using time series data, and integrating the latest statistical data from international organizations and executive surveys. TTCI is a benchmark for tourism competitiveness that measures a series of factors and policies that enable the sustainable development of the Travel \& Tourism (T\&T) sector that contributes to the development and competitiveness of a country; while preserving tourism assets, both natural and cultural, which are the mainstay of tourism. The TTCI report is the flagship product of the World Economic Forum that focuses on the future of mobility that unites the world and ensures that travel and transportation systems are able to meet the demands of the 21st century. This report serves as a strategic benchmark for policy makers, companies and complementary sectors to advance and develop. the travel and tourism sector in the future. TTCI analysis is intended to provide an overview of the level of competitiveness of travel \& tourism at the country and regional levels. Although it is realized that the performance of a region / region does not always reflect the performance of a country because the performance of countries varies greatly in each region. TTCI consists of 4 sub indicts, 14 pillars and 90 indicators, namely: Enabling Environment, consists of 5 pillars ( 40 indicators), namely: Business Environment, 12 indicators:
a) Property rights
b) Impact of rules on FDI
c) Efficiency of legal framework in settling disputes 
d) Efficiency of legal framework in challenging regulations

e) Time required to deal with construction permits*

f) Cost to deal with construction permits*

g) Extent of market dominance

h) Time required to start a business*

i) Cost to start a business*

j) Extent and effect of taxation on incentives to work

k) Extent and effect of taxation on incentives to invest

l) Total tax rate*

a. Safety and Security, 5 indicators

1) Business costs of crime and violence

2) Reliability of police services

3) Business costs of terrorism

4) Index of terrorism incidence*

5) Homicide rate*

b. Health and Hygiene, 6 indicators

1) Physician density*

2) Use of basic sanitation*

3) Use of basic drinking water*

4) Hospital beds*

5) HIV prevalence*

6) Malaria incidence*

c. Human Resources and Labor, 9 indicators

d1. Qualification of the labor force

1) Primary education enrolment rate*

2) Secondary education enrolment rate*

3) Extent of staff training

4) Treatment of customers

d2. Labor market

5) Hiring and firing practices

6) Ease of finding skilled employees

7) Ease of hiring foreign labor

8) Pay and productivity

9) Female labor force participation

d. ICT Readiness, 8 indicators

1) ICT use for business-to-business transactions

2) Internet use for business-to-consumer transactions

3) Individuals using the internet*

4) Broadband internet subscribers*

5) Mobile telephone subscriptions*

6) Mobile broadband subscriptions*

7) Mobile network coverage*

8) Quality of electricity supply

1. T\&T Policy and Enabling Conditions, consists of 4 pillars (23 indicators), namely:

a. Prioritization of Travel and Tourism, 6 indicators

1) Government prioritization of the $T \& T$ industry

2) T\&T government expenditure* 
3) Effectiveness of marketing to attract tourists

4) Comprehensiveness of annual T\&T data*

5) Timeliness of providing monthly/quarterly T\&T data*

6) Country Brand Strategy rating*

b. International Openness, 3 indicators

1) Visa requirements*

2) Openness of bilateral Air Service Agreements*

3) Number of regional trade agreements in force*

c. Price Competitiveness, 4 indicators

1) Ticket taxes and airport charges*

2) Hotel price index*

3) Purchasing power parity*

4) Fuel price levels*

d. Environmental Sustainability, 10 indicators

1) Stringency of environmental regulations

2) Enforcement of environmental regulations

3) Sustainability of travel and tourism industry development

4) Particulate matter concentration*

5) Number of environmental treaty ratifications*

6) Baseline water stress*

7) Threatened species*

8) Forest cover change*

9) Wastewater treatment*

10) Fish stock status *

a. Infrastructure, consists of 3 pillars (17 indicators), namely: Air Transport Infrastructure, 6 indicators

1) Quality of air transport infrastructure

2) Available seat kilometres, domestic

3) Available seat kilometres, international*

4) Aircraft departures*

5) Airport density*

6) Number of operating airlines*

b. Ground and Port Infrastructure, 7 indicators

1) Quality of roads

2) Road density*

3) Paved road density*

4) Quality of railroad infrastructure

5) Railroad density*

6) Quality of port infrastructure

7) Ground transport efficiency

c. Tourist Service Infrastructure, 4 indicators
1) Hotel rooms*
2) Quality of tourism
3) Presence of major car rental companies*
4) Automated teller machines per adult population*

2. Natural and Cultural Resources, consists of 2 pillars (10 indicators), namely:

a. Natural and Cultural Resources, 5 indicators

1) Number of World Heritage natural sites* 
2) Total known species*

3) Total protected areas*

4) Natural tourism digital demand*

5) Attractiveness of natural assets

b. Cultural Resources and Business Travel, 5 indicators

1) Number of World Heritage cultural sites*

2) Number of oral and intangible cultural heritage expressions*

3) Number of sports stadiums*

4) Number of international association meetings*

5) Cultural and entertainment tourism digital demand*

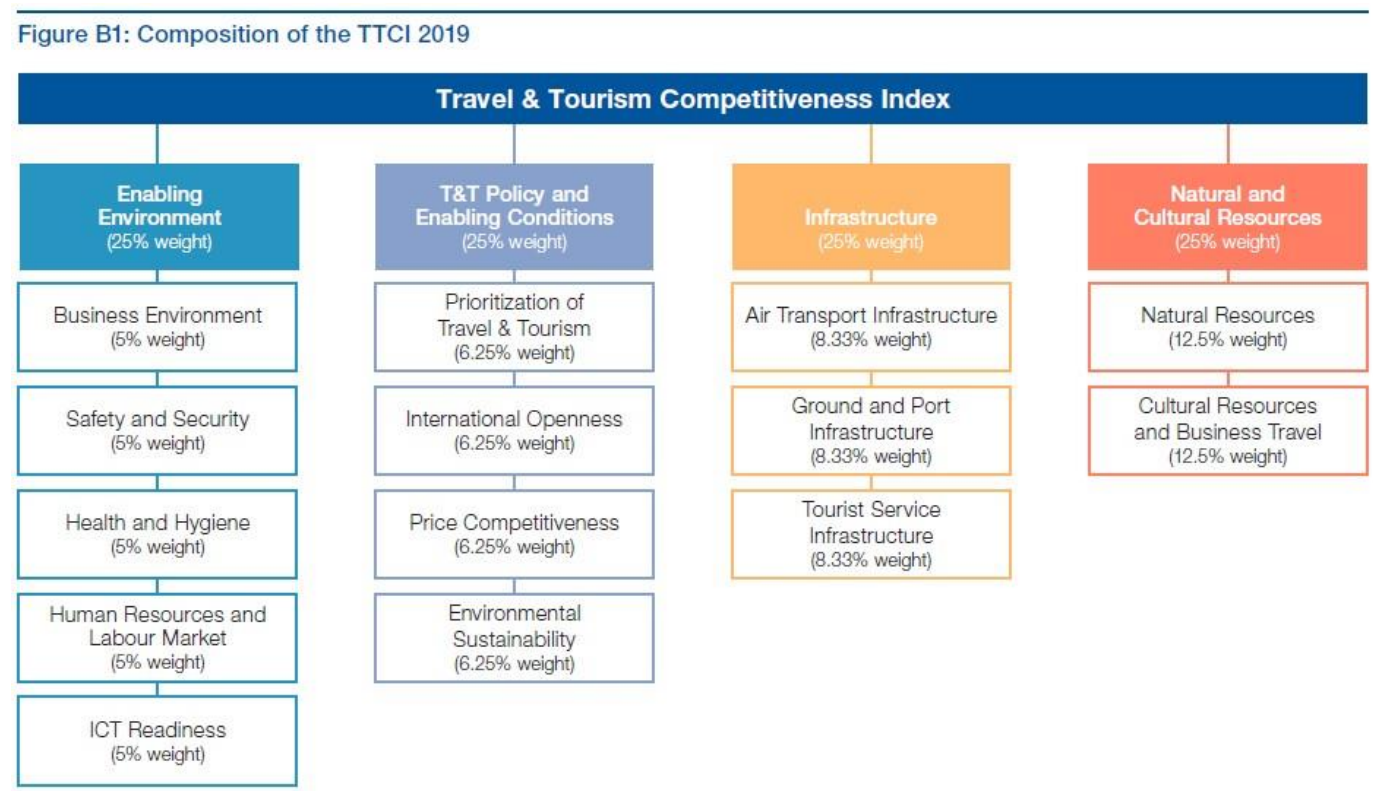

Figure 6 Sub-indices, pillars and indicators used in the 2019 TTCI Source: World Economic Forum, 2019

\section{E. Methodology}

A qualitative approach is used in this study to understand the growing phenomenon of halal tourism in Indonesia. This research qualitatively puts forward the process of communication and interaction between the researcher and the phenomenon under study. In addition, in line with (Cresswell, 2013) regarding a qualitative approach, this study seeks to provide a description of the data through systematic exposure, including data collection and reporting of research results.

The method used in this research is descriptive by trying to describe the condition of an object or a certain event originating from the visible reality, after which it is accompanied by efforts to draw universal conclusions based on facts (Farida, 2014).

\section{F. Result and Discussion}

Extensive use of technology is underway in the tourism sector. This has encouraged the development of a smart destination approach in tourism development. The smart destination initiative is carried out in an effort to build a viable tourism ecosystem. Technology helps better manage tourism and its impacts (social, cultural and environmental). Smart destinations can act as agents of positive change for 
more sustainable and competitive destinations (UNWTO, 2018). The development of smart destinations is not only always related to the application of technology in its implementation, but also closely related to real time information and communication services, interconnection, and efforts to improve synchronization and synergy among tourism actors.

Developing smart destinations in halal tourism destinations requires a new way of thinking about tourism management based on new possibilities facilitated by technology, adapted to local realities. smart halal destination is a geographical space (area) where the development of halal tourism is planned and implemented based on technological infrastructure, enabling sustainable local development while providing a quality experience for Muslim tourists and quality of life for local residents (Gretzel et.al, 2015). The application of the smart halal destination approach in developing halal tourism destinations is believed to be able to optimize the fulfillment of the specific needs of Muslim tourists. Muslim tourists can be more independent when collecting information from various sources to plan their trip. In addition, Muslim tourists use technology to enhance their experience in the halal tourist destinations they are visiting and share their travel experiences, which can encourage or even deter other tourists. Smart halal destinations can facilitate all halal travel experiences obtained in all processes: before, during, and after traveling to halal tourist destinations.

The challenge faced in implementing a smart halal destination is how to integrate innovative and smart solutions that maximize the travel experience, and in accordance with local realities. Coordination and sharing and systematic and widespread utilization of halal tourism data for value creation, efficient integrated systems and services is still a big challenge.

SMART Halal Destination is an "ecosystem that is effective, efficient, and integrated through a technology system, to build competitive Muslim-friendly destinations". The halal tourism ecosystem developed through the SMART Halal Destination concept is expected to have the following characteristics:

a) Effective: acting appropriately in a fast time.

b) Efficient: use resources wisely for maximum results.

c) Integrated: connected harmoniously and systematically.

d) Technological system: the use of an effective technology system to facilitate and utilize the development of the halal destination ecosystem.

e) Muslim friendly destinations: destinations that are able to impressively meet the specific needs, wants and experiences of Muslim travelers.

f) Competitiveness: growing in a superior way compared to competitors.

The application of the smart halal destination approach mentioned above is directed at creating values that include:

a) Economic value

b) Social value

c) Functional value

d) Emotional value

e) Epistemic/ knowledge value in order to realize benefits for improving the quality of human life.

The following is the development model for halal tourism SMART Halal Destination: 


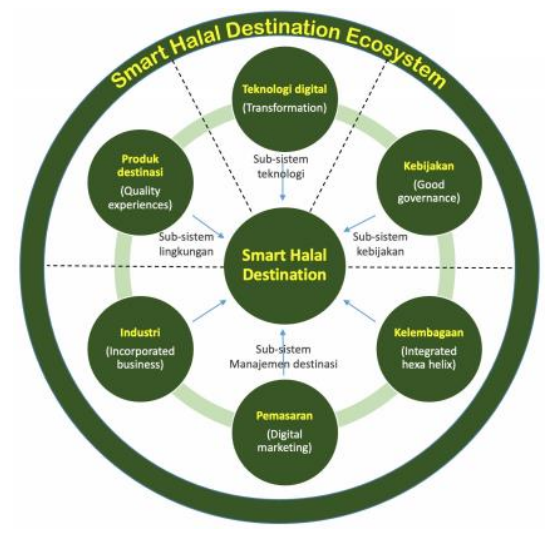

Figure 7 Model SMART Halal Destination

\section{Source: Sumaryadi, Sutono, Rahtomo, Puksi, Rumayar, 2020}

The Smart Halal Destination model consists of 4 sub-systems consisting of a technology sub-system, an environmental sub-system, a destination management sub- system, and a policy sub-system. All of these sub-systems are integrated with each other and as a whole have 6 dimensions consisting of digital technology, destination products, industry, marketing, institutions, and policies.

\section{Digital Technology}

Smart destinations are based on development optimization supported by seamless connections between high-quality information technology and physical infrastructure through sensors, smart devices, and big data management used in specific geographic areas (Gretzel et al., 2015b; Werthner et al., 2015). Because the tourism industry is one of the most suitable fields for the broad application of information technology from an operational and business point of view. The application of digital technology is very important to realize smart tourism (Gretzel et al., 2015b), digital technology is added as a new factor that connects core resources and attractiveness. Digital technology has a central role in building smart destinations, and at the same time, improving the quality of tourism destinations (Koo et al., 2016).

The digital technology aspect focuses on its function in the process of transforming destination governance through the development of technology that can improve connectivity and quality information services for stakeholders with an interest in halal tourism, both internal and external stakeholders.

The application of smart halal destinations in the aspect of digital technology includes:
a) Digital databases and information systems
b) Digital destination management
c) Digital industrial value chain
d) Tourist information based on mobile application.

\section{Destination Product}

The dimensions of the destination product are described in the concept of the destination mix as a synergy of physical product elements in the form of:

a) Attractiveness, accommodation, transportation and physical accessibility that

b) support the flow of tourists into the destination;

c) Program and event elements which constitute the availability of tourism activity programming, calendar of events which consist of festivals, expos, special events, exhibitions and other events which are packaged by involving elements of physical products and community elements; 
d) Tour package elements are elements that synergize elements of physical product elements and event programs in various types of package series of destination tour trips;

e) Community elements are elements of the host community and tourist community which become the supporting stimulus for the implementation of elements of physical products, programs and events as well as tour packages, through various roles and community involvement.

The destination product aspect focuses on developing tourism resources that include nature, culture, and man-made in a responsible manner, which is directed at creating quality experiences for Muslim tourists.

The application of smart halal destinations in the aspects of destination products includes:

\section{Quality attraction}
a) ICT amenities and infrastructure
b) Accessibility and safe transportation system
c) Thematic packages and programs / events
d) Standardization of destination Islamic attributes

\section{Industry}

The industrial dimension is an important factor in the ecosystem of halal tourism destinations, because it involves efforts in the product / supply sector to meet the needs of tourists as a whole. The form of escalation in the halal tourism industry includes several questions for elements of the business sector in answering:

a) Anything that must be produced from the business world to meet tourism demand in a certain form (for example, types of high-cost, high-cost, Muslim- friendly holiday package products, packages made specifically for or aimed at Muslim-friendly mass markets or other types of Muslim-friendly holidays).

b) When, where and how should Muslim friendly tourism products be provided (eg how to produce products that are supported by halal certification)

c) What form of business or business is needed on a priority scale at a destination, to meet the needs of tourism products and services so that Muslim-friendly requests are met?

The industrial aspect focuses on developing product innovation and corporated businesses in developing a competitive halal tourism ecosystem.

The application of smart halal destinations in industrial aspects includes:

a) Industrial product quality and innovation

b) Quality and creative product innovation

c) Product and industry standardization

d) Halal investment hub

\section{Marketing}

The marketing dimension in the smart halal destination model is functioned by the destination management subsystem group as a sequential and continuous process through a plan, research, tools, control and program evaluation carried out by the destination management organization (DMO), aiming to meet the needs and desires of tourists in accordance with the vision. , the goals and objectives of the destination and the destination manager (DMO) itself. To become an effective marketing manager for Muslim tourists, destination management marketing programs depend a lot on the efforts and synergy of various organizations and other individuals inside and outside the destination. The Marketing Model provides the following benefits: 

a) Offer clear information about Muslim friendly services and facilities at the
b) destination.
c) Save visitors time and energy, as a DMO one-stop shop is for the benefit of local tourism.
d) Providing various information on Muslim-friendly tourism products in
e) destinations.
f) Providing services to tourists (mostly) for free

The marketing aspect focuses on image development, strategy and marketing communications, including digital marketing partnerships in an effort to meet the specific needs and experiences of Muslim tourists.

The application of smart halal destinations in industrial aspects includes:
a) Digital marketing strategy
b) Unique experiential content
c) Promotion strategy and digital media
a. Customer engagement

\section{Intuitional}

The institutional dimension in the smart halal destination model is in the destination management sub-system, which is an effort to strengthen synergy in the implementation of halal tourism in destinations, institutional elements can form conducive governance and strengthen cooperation mechanisms between actors in the development of halal tourism. The institutional dimension of halal tourism in the smart halal destination ecosystem can strengthen the synchronization of the role of tourism human resources, research and research in the development of halal tourism.

The institutional aspect focuses on strengthening the synergy and collaboration of stakeholders (integrated hexa helix) in the context of realizing quality halal tourism governance.

The application of smart halal destinations in institutional aspects includes:
a) Organizing, communication and integration
b) Curriculum and center of excellence
c) Trace-ability system
d) Research and development

\section{Policy}

The policy dimension in the smart halal destination model is a policy subsystem, which in the function of the destination manager (DMO) is responsible for implementing sustainable policies and strategies in the field of halal tourism development, including the role of the regional legislature and executive in an effort to prepare regulations that support the implementation of halal tourism. until the smart halal destination is realized.

The following are efforts to accelerate smart halal destinations, if the policy dimensions are applied in the development of halal tourism:
a) Describing the plan to develop a smart halal destination in the master plan for
b) tourism development in the region
c) Formulation of a Strategic Action Plan (DSRA) for the development of regional halal tourism destinations.
d) Availability of technical guidelines for organizing halal tourism in the
e) regions. 
The policy aspect focuses on the availability of political policies and strategies including destination planning that shows alignments with the development of halal tourism and community welfare (good governance).

The application of smart halal destinations in policy aspects includes:

1) Master plan

2) Destination development priority

3) Industrial development and investment policies

\section{G. References}

Al-Qaradawi, Y. (2013). The Lawful and the Prohibited in Islam. Wisdom International School for Higher Education Studies (WISHES). Retrieved from https://books.google.com.my/books?id=iXCNAQAAQBAJ

Battour, M., \& Ismail, MN (2016). Halal tourism: Concepts, practises, challenges and future. Tourism Management Perspectives, 19, 150-154. https://doi.org/10.1016/i.tmp.2015.12.008

Battour, M., Ismail, MN, \& Battor, M. (2011). The impact of destination attributes on Muslim tourist's choice. International Journal of Tourism Research, 13(6), 527- 540. https://doi.org/10.1002/jtr.824

Chang, L.-L., Backman, KF, \& Huang, YC (2014). Creative tourism: a preliminary examination of creative tourists' motivation, experience, perceived value and revisit intention. International Journal of Culture, Tourism and Hospitality Research, 8(4). https://doi.org/10.1108/IJCTHR-04-2014-0032

Duman, T. (2011). Value of Islamic tourism offering: Perspectives from the Turkish experience. World Islamic Tourism Forum (WITF, 2011), Kualalumpur. Retrieved from http://www.iais.org.my/e/attach/ppts/12-13JUL2011- WITF/abstracts/abstracts.pdf

Eid, R., \& Hatem El-Gohary. (2014). Muslim Tourist Perceived Value in the Hospitality and Tourism Industry. Journal of Travel Research, (May). https://doi.org/10.1177/0047287514532367

Kementerian Pariwisata. (2019a). Panduan Penyelenggaraan Pariwisata halal. Jakarta: Kementerian Pariwisata RI.

Kementerian Pariwisata. (2019b). Rencana Strategis Pengembangan Pariwisata Halal 2019-2024. Jakarta: Kementerian Pariwisata RI.

Koo, C., Shin, S., Gretzel, U., Hunter, WC, \& Chung, N. (2016). Conceptualization of Smart Tourism Destination Competitiveness. Asia Pacific Journal of Information Systems, 26(4), 561-576. https://doi.org/10.14329/apjis.2016.26.4.561

Mastercard - Crescent Rating. (2019). Global Muslim Travel Index 2019. Singapore: Mastercard Crescent Rating.

Morrison, AM (2013). Marketing and Managing Tourism Destinations (1st ed.). New York: Routledge. https://doi.org/10.4324/9780203081976

Pizam, A., Neumann, Y., \& Reichel, A. (1978). Dimentions of Tourist Satisfaction with a Destination Area. Annals of Tburism Research, 5(3), 314-322.

Razzaq, S., Hall, CM, \& Prayag, G. (2016). The capacity of New Zealand to accommodate the halal tourism market - Or not. Tourism Management Perspectives, 18, 92-97. https://doi.org/10.1016/j.tmp.2016.01.008

Ritchie, JRB, \& Crouch, GI (1999). Tourism, Competitiveness, and Societal Prosperity.

Journal of Business Research, 44(3), 137-152. https://doi.org/10.1016/S0148- 2963(97)00196-3

Ritchie, JRB, \& Crouch, GI (2010). A model of destination competitiveness/ sustainability: Brazilian perspectives. Revista de Administração Pública, 44(5), 1049-1066. https://doi.org/10.1590/s0034-76122010000500003

Shakona, M., Backman, K., Backman, S., Norman, W., Luo, Y., \& Duffy, L. (2015).

Understanding the traveling behavior of Muslims in the United States. International Journal of Culture, Tourism and Hospitality Research, 9(1), 22-35. https://doi.org/10.1108/IJCTHR05-2014-0036 
Tribe, J., \& Snaith, T. (1998). From SERVQUAL to HOLSAT : holiday satisfaction in Varadero, Cuba. Tourism Management, 19(I), 25-34. https://doi.org/10.1016/S0261-5177(97)00094-0

Truong, T., \& Foster, D. (2006). Using HOLSAT to evaluate tourist satisfaction at destinations : The case of Australian holidaymakers in Vietnam. Tourism Management, 27(5), 842-855. https://doi.org/10.1016/j.tourman.2005.05.008

Wall, G., \& Mathieson, A. (2006). Tourism: Change, Impacts, and Opportunities (1st ed.). Harlow, England: Pearson Education Limited.

Weidenfeld, A., \& Ron, AS (2008). Religious needs in the tourism industry. Anatolia, 19(2), 357-361. https://doi.org/10.1080/13032917.2008.9687080

World Economic Forum. (2019). The Travel \& Tourism Competitiveness Report 2019. Geneva: World Economic Forum.

Zamani-farahani, H., \& Henderson, JC (2010). Islamic Tourism and Managing Tourism: develop. Inter, 89(July 2009), 79-89. https://doi.org/10.1002/jtr.741 